\title{
ULTRAVIOLET LIGHT EFFECTS ON PRODUCTIVE, PHYSIOLOGICAL PERFORMANCE AND IMMUNE RESPONSE OF TWO DEVELOPED LAYING HENS
}

\section{Youssef $^{1^{\star}}$ A.M.D., El-Wardany ${ }^{2}$ I., Hassan ${ }^{1}$ M.S.H. and Shourrap ${ }^{2}$ M.I.A.}

1- Animal Prod. Res. Inst., Agric. Res. Center, Giza, Egypt

2- Poultry Production Dept., Fac. of Agric., Ain Shams Univ., P.O. Box 68, Hadayek Shoubra 11241, Cairo, Egypt

*Corresponding author: a youssef007@yahoo.com

Received 6 May, 2019

Accepted 4 September, 2019

\section{ABSTRACT}

In this experiment, a total number of 165 birds (150 female + 15 male) from each developed laying hens Silver Montaza and Matrouh layer 20 weeks old up to 40 weeks of age. All bids were weighted and randomly distributed into 5 groups with three replicates per treatment (10 females and 1 male / replicate) with almost similar initial average body weight. Each experimental group was exposed to natural day light and supplemented with Ultraviolet light as in its program light, the main group (control group) exposed to no UV light, the second, third, fourth and fifth groups were exposed to $1,2,3$ and 4 hours/day respectively to UV light from UV lamps after sunset, and controlled by a timer as following:

1- Hens in the first treatment (Control) were exposed to sun light and yellow lamps to $17 \mathrm{~h} /$ day without exposed to UV lamps.

2- Hens in the second treatment were exposed to sun light to sunset, UV lamps for $1 \mathrm{~h} /$ day and supplemented with yellow lamps to the end of light period.

3- Hens in the third treatment were exposed to sun light to sunset, UV lamps for $2 \mathrm{~h} /$ day and supplemented with yellow lamps to the end of light period.

4- Hens in the fourth treatment were exposed to sun light to sunset, UV lamps for 3h/day and supplemented with yellow lamps to the end of light period.

5- Hens in the fifth treatment were exposed to sun light to sunset and UV lamps for 4h/day without exposed to yellow lamps. Birds were reared under similar condition.
The consequences indicated that live body weight (LBW), feed intake (FI), egg mass, some blood components, immune responses to sheep red blood cells were significantly improved $(\mathrm{P} \leq 0.05)$ by exposed birds to UV lamps after sunset supplemented in its program light. It could be concluded that the efficient exposed time to UV lamps was (2-3 hours/day) for silver Montaza and Matrouh developed laying hens.

Keywords: Ultraviolet lamps; Laying hens; Program light; Productive performance

\section{INTRODUCTION}

The performance of domestic poultry is a function of their genetic potential and their interaction with the environmental conditions such as light. Understanding the role of light in poultry production and managing in the proper way allows producers to apply the best lighting program and make decisions to optimize the performance parameters and minimize productive costs. Light is important for chicken vision as pre-dominant sense in birds, where a large proportion of the total brain size is devoted to eyes and visual cortex (Güntürkün, 2000). Light influences physical activity, metabolic rate, and other physiological factors like reproduction and hormonal status. Visible light is proper a small portion of the total electromagnetic spectrum, which contains radio waves, nuke, $x$-rays and gamma defile. The publicity environment can be classified into three ways: wavelength, intenseness and continuance. Each of these will be dissipate. Light is a serious factor of fowl product. Currently, there is a wide diversity of lighting playbill. Olanrewaju et al (2006). The agreement of new 
light sources in the chick industry offers producers the benefits of improved lighting efficiency and longer lamp life resulting in long-term cost savings. Ultraviolet light is an electromagnetic radiation with a wavelength from (100-400 nm.) shorter than the visible light but lengthier than $\mathrm{x}$-rays. UV light is subjectively fractured down in to three bands, according to its subjective effects: UVA, UV-B and UV-C.

UV-A, often called 'black light', is the least hurtful ask it has the least force and is the most common token of UV day found in artificial light sources. UV-A ranges from 315 - 400 nm (Ryer, 1997) although definitions vary. It is us interest for its capability to mainspring fluorescent materials to emit macroscopic light and along it is relatively harmless. Most phototherapy and burning beds necessity UV-A lamps.

UV-B ranges from 280 - $315 \mathrm{~nm}$ (Ryer, 1997) and is usually the most deadly formality of UV light because it has adequate energy to damage biologic prosenchyma, yet not entirely enough to be fully engrossed by the atmosphere.

Wavelengths between 100 to $280 \mathrm{~nm}$, called UV-C (Ryer, 1997), are almost completely absorbed in air due to their high-energy photons colliding with oxygen atoms motive the form of ozone. Germicidal UV-C lamps are frequently used to filter air and water that of their ability to destroy bacteria.

The bird uses this UV light for behaviors such as reproduction and feeding. When any bird is not kept outside, UV light should be provided to allow for natural behavior. UV perception also, plays a major role in the choosing intake of food. Ultraviolet lighting is important for calcium metabolism. Exposure to UV light increased body weight, bone ash, and dialyzable $\mathrm{P}$ and decreased the incidence and severity of TD. Plasma $\mathrm{Ca}$ and feed efficiency was unaffected by UV light (Mitchell et al 1997). Zhang et al (2006) showed that body weight at the second week significantly improved by $3.86 \%$ vie with the govern $(P<0.01)$, and significantly improved by $2.55 \%$ at the sixth week $(P<0.05)$. The realization of ultraviolet radiation on shank size was during the previous four weeks. The shank size significantly improved by 1.61 and $1.31 \%$ during the 2nd week and the 3rd week, regardfully. They concluded that Skeleton development; skeleton quality was improved by ultraviolet radiation light and the growth performance was improved by $1.4 \%$ averagely in broiler.
Zhang, (2000) presented that ultraviolet radiation aid $\mathrm{GH}$ to release, improved the activity of ostosis cells, and enlarged the formature of skeleton. On the other side, intestinal Ca prepossession was promoted, twist movement was heightened in stomach and intestine, protein absorption degree was increased, and rich ingredients were provided that to the new skeleton. Hence, skeletal mineralization was elevated.

Insect traps that use ultraviolet light as an attractant have been shown to have no adverse manifestation on egg composition in mature caged layers (Hogsette et al 1997).

(Carien et al 2003) found that egg production, fertility, mortality and observed sexual behavior were not affected by the light treatments. Yet, differences in the light sources' qualities or differing intensities had some behavioral effects that influenced ground eggs, feather condition and injury scores as hatchability.

Zhang et al (2006) showed that serum Ca and $P$ satisfy were amended with ultraviolet radiation, and showed that ultraviolet radiation was useful in incremental the intestinal $\mathrm{Ca}$ and $\mathrm{P}$ absorption and give $\mathrm{Ca}$ and $\mathrm{P}$ raise. Serum $\mathrm{Ca}$ and $P$ had significant contest in the third week $(P<0.05)$ and indicated that the development of the chicken's skeleton happened quickly in the early phases, and $\mathrm{Ca}$ absorption was improved and skeleton mineralization was promoted. However, in the sixth week, the difference was not significant $(P>0.05)$; the motive may be because of the maturity of chickens. It was detail T3, calcitonin, vitamins and other factors could maintain standard $\mathrm{Ca}$ content in disposition, and self-assertive continuity of other functions. The physiological agency of light occurs when it is received by eye and born again into resolution impulses that are sent to the brain. The brain then organizes the impulse to influence the pituitary gland to hide the requirement hormones for ovulation (Lewis and Morris 2000).

Bacteria may contaminate eggshells in two possible ways: vertically or horizontally. Vertical transmission happen in the generative organs of corrupt hens mainly from implication of ovaries by systemic infection or ascending infection from contaminated cloaca into the vagina and inferior regions of the oviduct (Miyamoto et al 1997). Horizontal transmission happen when eggs are afterwards exposed to a contaminated environment and microorganisms soak the eggshell. Eggs are potently corrupted by any surface with which 

response of two developed laying hens

they appear into terminal. Sources of bacterial taint of the shell include caging material, nesting materials, water, hands, broken eggs, consanguinity, insects, and conveyance belting though pother, country, and feces (Davies and Breslin, 2003). The bacterial fouling of eggshells can be inclined by several factors such as e.g. the concentration of bacteria in the aria of the fowl house (De Reu et al 2005a).

Ultraviolet light (UV) is widely used for various fare and water sanitation preserver, the engrossment of UV by living tissue origin a photochemical retroaction that has the capability to modify the hereditary material (DNA and RNA) of a cell (Koutchma et al 2009) consequently, UV is fatal and germicidal by inhibiting aerobic bacteria, yeast, and mold populations from successful repetition (Gao et al 1997). In fowl sweep, UV was the most frequently used for egg disinfection with not negative influence on the embryo (Coufal et al 2003).

Koutchma et al (2009) specify that UV dose requirements for slay microbial cells are relatively costly and hanging on the microorganism, earnestness and exposure time. The range of UV wavelength is placed between 200 and $400 \mathrm{~nm}$ and is split to three partitions: UV-A (Long wave and black light with $315-400 \mathrm{~nm}$ ), UV-B (medium wave with 280 to $315 \mathrm{~nm}$ ) and UV-C (deficient wave and antiseptic with 200 to $280 \mathrm{~nm}$ ) (Turtoi and Borda 2014).

Also, the poultry industry rise and preferred concrete floor bedding induced generation of liquid waste - slurry, which proves to be very dangerous owing to the presence of pathogens. The group dominant among the pathogenic bacteria was Enterobacteriaceae genus: Escherichia coli, Salmonella spp., Shigella spp., Klebsiella spp., Proteus spp. slightly lower numbers were detected of Gram-negative cocci: Staphylococcus spp., Bacillus spp., anaerobic Clostridium spp., fungi of the genus Aspergillus, Penicillium, Trichoderma, Geotrichum as anascogenic Candida or Cryptococcus (Roy et al 2002). Microbes were also recovered from the birds themselves, bedding material, feedstuffs supplied and water.

Suitable raising conditions of chicken broilers need the best indoor microclimatic conditions and administration of proper feed mixtures (Gornowicz 2004).
Two studies recognized that the $\mathrm{pH}$ stability of avian influenza virus (AIV) ( $\mathrm{H} 5$ and $\mathrm{H} 7)$ was best among $\mathrm{pH} 5.5-8.0$. At a $\mathrm{pH}$ of 2 at $56^{\circ} \mathrm{C}$ the virus stay alive only 30 minutes (Lu et al 2003).

Also, Ultraviolet light has been used to terminate microbes. UV light cannot pass through even a thin glass. UV light may be used to destroy AIV in infected fecal material (Kamlang et al 2006).

Ultraviolet light traps could be used in fly controlling programs with no adverse effects on the birds (Hogsette et al 1999).

\section{MATERIALS AND METHODS}

The experiment in the current study was conducted in Inshas poultry breeding station, Animal production Research Institute, Agricultural Research Center, Ministry of Agriculture, Giza, Egypt.

\section{Experimental procedures}

\section{Experimental birds}

One hundred and sixty five from each developed Strains Silver Montaza and Matrouh (150 females and 15 males) 20 weeks old were used in this experiment up to 40 weeks of age. All bids were weighted and randomly distributed into five treatments with three replicates per treatment $(10$ females and 1 male / replicate) for each developed strain with almost similar initial average body weight. The experimental was started at $20 \mathrm{wks}$ of age and ended at 40 wks of age, collected data were presented at 4-week interval period. Each experimental group was exposed to natural day light and supplemented with Ultraviolet light, the first group (control group) exposed to no UV light, the second, third, fourth and fifth groups were exposed to 1,2, 3 and 4 hours respectively to UV light from UV lamps after sunset, and we used timer to controlled of this.

\section{Experimental diet}

The chemical composition of the layer diet is shown in Table (1). 
Table 1. Chemical Composition and calculated analysis of experimental diets

\begin{tabular}{|c|c|}
\hline 7 & $\begin{array}{l}\text { Layer diet } \\
(20-40 \mathrm{~W})\end{array}$ \\
\hline \multicolumn{2}{|l|}{ Ingredient } \\
\hline Yellow corn & 69.4 \\
\hline Soybean Meal (44\%) & 13 \\
\hline Layer concentrate & 10 \\
\hline Bone Meal & 1 \\
\hline Limestone & 6.5 \\
\hline Premix & \\
\hline Salt & \\
\hline DL-Methionine & 0.1 \\
\hline Total & 100.00 \\
\hline \multicolumn{2}{|l|}{ Calculated analysis } \\
\hline Crude Protein \% & 16.5 \\
\hline Metabolizable Energy (kcal/kg) & 2900 \\
\hline Calcium \% & 3.6 \\
\hline Phosphorus \% & 0.53 \\
\hline Methionine \% & 0.4 \\
\hline Lysine \% & 0.8 \\
\hline
\end{tabular}

${ }^{*}$ Each kilogramme of layer concanterate contains: crude protein $51.00 \%$, Metabolizabale energy $2400 \mathrm{kcal} / \mathrm{diet}$, Calcium $8.00 \%$, Lysine, $3.3 \%$, Crude fiber, $2.00 \%$, Crude fat, $6.40 \%$, Availble phosphoras, $3.00 \%$. The following levels of vitamins and minerals: Vit. A 10,000 IU; Vit $D_{3}$ 2,500 IU; Vit. E 100 mg; Vit. K 25 mg; Vit. $B_{1}$ 2,00 mg; Vit. $B_{2} 40$ mg; Vit. $B_{6} 15$ mg; Vit. $B_{12} 200$ mg; Pantothenic acid 100 mg; Niacin 400 mg; Biotin 500 mg; Folic acid 10 mg; Choline chloride $500 \mathrm{gm}$; Selenium $1 \mathrm{mg}$; Copper 5 $\mathrm{mg}$; Iron $400 \mathrm{mg}$; Manganese $620 \mathrm{mg}$; Zinc $560 \mathrm{mg}$; lodine $3 \mathrm{mg}$; Antioxidant $75 \mathrm{mg}$.

${ }^{* *}$ Premix contain per $3 \mathrm{~kg}$ : Vit. A 12,000,000 IU; Vit D3 3,000,000 IU; Vit. E 50,000 mg; Vit. K3 3,000 mg; Vit. B1 2,000 mg; Vit. B2 7,500 mg; Vit. B6 3,500 mg; Vit. B12 $15 \mathrm{mg}$; Pantothenic acid 12,000 mg; Niacin 30,000 mg; Biotin $150 \mathrm{mg}$; Folic acid $1,500 \mathrm{mg}$; Choline $300 \mathrm{gm}$; Selenium 300 mg; Copper 10,000 mg; Iron 40,000 mg; Manganese 80,000 mg; Zinc 80,000 mg; lodine 2,000 $\mathrm{mg}$; Cobalt $250 \mathrm{mg}$; $\mathrm{CaCO} 3$ 3,000 mg.

*** Calculated according to NRC (1994) and layer concentrates

\section{Experimental design}

Five treatment groups per strain were applied as follows:

1- Hens in the first treatment were exposed to sun light and yellow lamps to $17 \mathrm{~h} /$ day without exposed to UV lamps (Control).

2- Hens in the second treatment were exposed to sun light to sunset, UV lamps for $1 \mathrm{~h} /$ day and supplemented with yellow lamps to the end of light period.

3- Hens in the third treatment were exposed to sun light to sunset, UV lamps for $2 \mathrm{~h} /$ day and supplemented with yellow lamps to the end of light period.

4- Hens in the fourth treatment were exposed to sun light to sunset, UV lamps for 3h/day and supplemented with yellow lamps to the end of light period.

5- Hens in the fifth treatment were exposed to sun light to sunset and UV lamps for 4h/day without exposed to yellow lamps.

\section{Management and housing}

Birds of all experimental groups were reared during the experimental period in suitable experimental pens in open floor rooms $(2 \mathrm{~m} \times 1.5 \mathrm{~m}=$ $3 \mathrm{~m}^{2}$ ). Water and diet were supplied ad libitum and all birds were kept under the same managerial and hygienic conditions, and 17 L: $7 \mathrm{D}$ photoperiod was maintained during the whole laying period.

\section{Measurements}

\section{Productive Performance}

Body weight (BW) was recorded during five periods (20-24, 24- 28, 28- 32, 32- 36 and 36- 40 weeks of age) from the beginning to the end of the experiment. Feed intake (FI) of each replicate was recorded every 28 days in $\mathrm{g} / \mathrm{hen}$. Egg mass was determined from the equation Egg mass= (average egg number/day) $X$ (average egg weight)

\section{Physiological and Biochemical parameters}

Blood samples were collected at the end of the research to collect Plasma Tri- iodothyronine (T3) (ng/dl) were measured, Total protein (TP) $(\mathrm{g} / \mathrm{dl})$, albumin (Alb) (g/dl), uric acid (UC), Alanine aminotransferase $(\mathrm{ALT})(\mathrm{U} / \mathrm{l})$, aspartate aminotransferase (AST) (U/l) and Globulin (g/dl). Blood plasma concentrations were determined spectrophotometrically using commercial kits that were done at Animal production Research Institute- Poultry Breeding Department.

\section{Humeral Immune responses}

Plasma samples were collected seven days after the first and the second immunization to estimate the primary and secondary antibody re- 

response of two developed laying hens

sponses as described by Benjamin et al (1980). Hens were injected with diluted sheep red blood cells, pull blood samples to appreciation first and second immune response.

\section{Statistical analysis}

The statistical analyses of data were done using SAS (2001), procedures. In a complete randomized design, the experimental group was 11 birds per replicate ( 10 female +1 male). The linear model included the main effect of lead and $\mathrm{Cr}$ levels as their interactions, and the strain type.

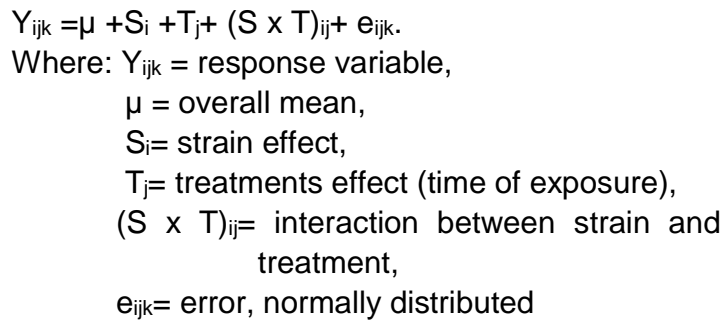

The statistical significance was set at $P \leq 0.05$. Differences among treatment means were detected using Duncan`s multiple range test (Duncan, 1955).

\section{RESULTS AND DISCUSSION}

\section{Productive performance}

The average live body weight at the beginning of the experiment ranged between 1103 and 1149 grams for Silver Montaza and Matrouh strains. The non-significant difference between the experimental groups for initial body weight indicated that the groups at the beginning of the experiment were homogenous.

\subsection{Live body weight}

\subsubsection{Effect of strain}

Table (2) showed that Live body weight at all experimental period (20-40 wks. of age) were significantly $(\mathrm{P}<0.05)$ affected by strain type. Silver Montaza developed strain recorded high live body weight at all experimental period, the average live body weight was 1413 grams compared to Matrouh developed strain that recorded lower live body weight at all the experimental period, and the average live body weight was 1317 grams this is may be because of the Silver Montaza strain cre- ated from crossing Rhode Island red (as dual purpose breed) males with Dokki-4 females, while Matrouh strain created from crossing White Leghorn (as egg type breed) males with Dokki-4 females (Mahmoud et al 1974 a \& b).

\subsubsection{Effect of Ultra Violet (UV) light}

Initial live body weight was non-significant differences between all UV exposure times (Table 2). Body weight was increasing with increasing in age and the best body weight in 24 and 28 wks. of age was in treatment 3 ( 2 hours UV exposure time) (1281 and 1374 grams respectively) while in 32,36 and 40 wks. of age was in treatment 4 ( 3 hours UV exposure time) (1473, 1566 and 1613 grams respectively) and the best average body weight from 20 to 40 wks. of age was in treatment 4 (3 hours UV exposure time) compared with control treatment (Table 2). These consequences agree with Mitchell et al (1997) and Zhang et al (2006) who reported that body weight at the 2 nd week significantly increased by $3.86 \%$ and significantly improved by $2.55 \%$ at the sixth wk. $(P<0.05)$. That may be because of the encouraging effect of Ultraviolet radiation light on shank size and growth performance.

\subsection{Feed intake}

\subsubsection{Effect of strain}

Feed intake in only period (28-32) wks. of age was significant affected by strain type compared with other experimental period (Table 3). Silver Montaza developed strain recorded the lower feed intake (116 gram/hen/day) compared with Matrouh developed strain (122 gram/hen/day). These results agree with Habeb et al (2007) who reported that there were non-significant differences between local strains for feed conversion during the growing period. On the other side, El-Hossari and Dorgham (1992) reported that Silver Montaza birds are heavier in LBW than Matrouh birds and it's well known that the heavier strains consume more feed than lighter ones due to increasing their maintenance requirements.

\subsubsection{Effect of Ultraviolet (UV) light}

Feed intake was significantly $(\mathrm{P}<0.05)$ affected by Ultraviolet exposure time in just two experimental period (Table 3). 
Table 2. Live Body Weight $(\mathrm{g})(\bar{X} \pm S E)$ of Silver Montaza and Matrouh layers as affected by Ultraviolet light during the different experimental periods

\begin{tabular}{|c|c|c|c|c|c|c|c|}
\hline \multirow[b]{2}{*}{ Treatment } & \multicolumn{7}{|c|}{ Live body weight (g) } \\
\hline & $\begin{array}{c}20 \text { wks } \\
\text { (Initial body } \\
\text { weight) }\end{array}$ & 24 wks & 28 wks & 32 wks & 36 wks & $\begin{array}{l}40 \text { wks (Final } \\
\text { body weight) }\end{array}$ & $\begin{array}{c}\text { Average } \\
(20-40 \text { wks })\end{array}$ \\
\hline Strain & * & * & * & * & * & * & * \\
\hline Silver Montaza & $\begin{array}{c}1164.67 \pm \\
11.16^{a}\end{array}$ & $\begin{array}{c}1309.00 \pm \\
11.66^{a}\end{array}$ & $\begin{array}{c}1381.40 \pm \\
6.96^{\mathrm{a}}\end{array}$ & $\begin{array}{c}1464.13 \pm \\
10.40^{\mathrm{a}}\end{array}$ & $\begin{array}{c}1557.87 \pm \\
15.05^{\mathrm{a}}\end{array}$ & $\begin{array}{c}1600.33 \pm \\
14.41^{\mathrm{a}}\end{array}$ & $\begin{array}{c}1413.00 \pm \\
9.26^{\mathrm{a}}\end{array}$ \\
\hline Matrouh & $\begin{array}{c}1088.67 \pm \\
10.25^{b}\end{array}$ & $\begin{array}{c}1209.00 \pm \\
11.66^{b}\end{array}$ & $\begin{array}{c}1295.67 \pm \\
10.66^{\mathrm{b}}\end{array}$ & $\begin{array}{c}1376.67 \pm \\
15.49^{b}\end{array}$ & $\begin{array}{c}1449.33^{ \pm} \\
15.03^{\mathrm{b}}\end{array}$ & $\begin{array}{c}1484.20 \pm \\
18.63^{b}\end{array}$ & $\begin{array}{c}1317.20 \pm \\
11.56^{\mathrm{b}} \\
\end{array}$ \\
\hline Ultraviolet light & NS & * & * & * & * & * & * \\
\hline Without & $\begin{array}{c}1112.50 \pm \\
21.16\end{array}$ & $\begin{array}{c}1255.83 \pm \\
28.36^{\mathrm{ab}}\end{array}$ & $\begin{array}{c}1320.00 \pm \\
28.14^{\mathrm{b}}\end{array}$ & $\begin{array}{c}1372.67 \pm \\
36.30^{c}\end{array}$ & $\begin{array}{c}1462.67 \pm \\
42.15^{\mathrm{b}}\end{array}$ & $\begin{array}{c}1476.67 \pm \\
45.90^{c}\end{array}$ & $\begin{array}{c}1333.33 \pm \\
32.09^{c}\end{array}$ \\
\hline 1 hour & $\begin{array}{c}1130.83 \pm \\
28.21\end{array}$ & $\begin{array}{c}1265.83 \pm \\
28.44^{\mathrm{ab}}\end{array}$ & $\begin{array}{c}1337.67 \pm \\
27.52^{\mathrm{b}}\end{array}$ & $\begin{array}{c}1403.50 \pm \\
27.72^{\mathrm{bc}}\end{array}$ & $\begin{array}{c}1485.17 \pm \\
32.39^{b}\end{array}$ & $\begin{array}{c}1539.50 \pm \\
35.01^{b c}\end{array}$ & $\begin{array}{c}1360.33 \pm \\
29.30^{\mathrm{abc}}\end{array}$ \\
\hline 2 hour & $\begin{array}{c}1149.17 \pm \\
17.10\end{array}$ & $\begin{array}{c}1281.67 \pm \\
30.18^{\mathrm{a}}\end{array}$ & $\begin{array}{c}1374.83 \pm \\
12.53^{\mathrm{a}}\end{array}$ & $\begin{array}{c}1440.83 \pm \\
18.79^{\mathrm{ab}}\end{array}$ & $\begin{array}{c}1500.00 \pm \\
28.77^{\mathrm{ab}}\end{array}$ & $\begin{array}{c}1550.83 \pm \\
28.56^{\mathrm{ab}}\end{array}$ & $\begin{array}{c}1383.17 \pm \\
20.30^{\mathrm{ab}}\end{array}$ \\
\hline 3 hour & $\begin{array}{c}1137.50 \pm \\
27.53\end{array}$ & $\begin{array}{c}1270.00 \pm \\
25.30^{\mathrm{ab}}\end{array}$ & $\begin{array}{c}1342.00 \pm \\
19.45^{\mathrm{ab}}\end{array}$ & $\begin{array}{c}1473.00 \pm \\
19.38^{\mathrm{a}}\end{array}$ & $\begin{array}{c}1566.67 \pm \\
22.44^{\mathrm{a}}\end{array}$ & $\begin{array}{c}1613.33 \pm \\
24.74^{\mathrm{a}}\end{array}$ & $\begin{array}{c}1400.50 \pm \\
21.47^{\mathrm{a}}\end{array}$ \\
\hline 4 hour & $\begin{array}{c}1103.33 \pm \\
21.93\end{array}$ & $\begin{array}{c}1221.67 \pm \\
28.68^{b}\end{array}$ & $\begin{array}{c}1318.17 \pm \\
21.70^{\mathrm{b}}\end{array}$ & $\begin{array}{c}1412.00 \pm \\
19.22^{b c}\end{array}$ & $\begin{array}{c}1503.50 \pm \\
27.48^{\mathrm{ab}}\end{array}$ & $\begin{array}{c}1531.00 \pm \\
24.16^{\mathrm{bc}}\end{array}$ & $\begin{array}{c}1348.17 \pm \\
22.10^{\text {bc }}\end{array}$ \\
\hline
\end{tabular}

$(\bar{X} \pm S E)=$ Average \pm standard error. $\quad$ NS $=$ Not significant.

$a, b$ and $c$ means having diverse letters at the similar column are significantly $(P \leq 0.05)$ different.

Table 3. Feed Intake $(\bar{X} \pm S E)$ of Silver Montaza and Matrouh layers as affected by Ultraviolet light during the different experimental periods

\begin{tabular}{|l|c|c|c|c|c|c|}
\hline \multirow{2}{*}{ Treatment } & \multicolumn{7}{|c|}{ Feed Intake (g/hen/day) } \\
\cline { 2 - 7 } & $20-24$ & $24-28$ & $28-32$ & $32-36$ & $36-40$ & $20-40$ wks \\
\hline Strain & NS & NS & $*$ & NS & NS & NS \\
Silver Montaza & $102.43 \pm 1.31$ & $86.05 \pm 1.35$ & $116.24 \pm 2.02^{\mathrm{b}}$ & $80.75 \pm 1.83$ & $158.66 \pm 2.94$ & $108.83 \pm 1.06$ \\
Matrouh & $99.12 \pm 1.90$ & $84.15 \pm 1.66$ & $122.00 \pm 1.97^{\mathrm{a}}$ & $77.35 \pm 1.91$ & $164.62 \pm 5.99$ & $109.45 \pm 1.43$ \\
\hline Ultraviolet light & $*$ & $*$ & $\mathrm{NS}$ & $\mathrm{NS}$ & $\mathrm{NS}$ & $\mathrm{NS}$ \\
Without & $103.94 \pm 3.50^{\mathrm{a}}$ & $85.87 \pm 1.99^{\mathrm{ab}}$ & $124.43 \pm 3.02$ & $76.33 \pm 2.77$ & $152.97 \pm 6.26$ & $108.71 \pm 1.48$ \\
1 hour & $96.13 \pm 2.73^{\mathrm{b}}$ & $90.14 \pm 1.91^{\mathrm{a}}$ & $122.70 \pm 2.54$ & $82.17 \pm 3.81$ & $166.64 \pm 4.39$ & $111.56 \pm 1.63$ \\
2 hour & $100.95 \pm 2.30^{\mathrm{ab}}$ & $81.08 \pm 2.94^{\mathrm{b}}$ & $116.86 \pm 3.28$ & $80.47 \pm 3.23$ & $157.13 \pm 5.24$ & $107.30 \pm 1.87$ \\
3 hour & $102.34 \pm 2.06^{\mathrm{ab}}$ & $83.86 \pm 2.07^{\mathrm{ab}}$ & $114.82 \pm 3.09$ & $76.47 \pm 2.59$ & $168.19 \pm 12.92$ & $109.14 \pm 2.97$ \\
4 hour & $100.52 \pm 2.02^{\mathrm{ab}}$ & $84.56 \pm 1.87^{\mathrm{ab}}$ & $116.81 \pm 3.77$ & $79.82 \pm 2.73$ & $163.28 \pm 5.83$ & $109.00 \pm 1.78$ \\
\hline$X$
\end{tabular}

$(\bar{X} \pm S E)=$ Average \pm standard error. $\quad \mathrm{NS}=$ Not significant.

${ }^{a}$ and ${ }^{b}$ means having diverse letters at the similar column are significantly $(P \leq 0.05)$ different. 
In (20-24) wks. of age treatment 2 (1 hour UV) recorded lower feed intake $(96 \mathrm{~g} / \mathrm{h} / \mathrm{d})$ compared with control $(103 \mathrm{~g} / \mathrm{h} / \mathrm{d})$.

In (24-28) wks. of age treatment 3 (2 hour UV) recorded lower feed intake $(81 \mathrm{~g} / \mathrm{h} / \mathrm{d})$ compared with other treatment.

These consequences agree with Zhang (2000) and Zhang et al (2006) who reported that under Ultraviolet radiation light enhanced in stomach and intestine, protein absorption degree was increased, and the growth performance was improved.

\subsection{Egg mass}

\subsubsection{Effect of strain}

Egg mass wasn't significant affected by strain type in all experimental period except in (32-36) wks. of age (Table 4).

In (32-36) wks. of age, Matrouh layer recorded higher egg mass $(825 \mathrm{~g})$ compared with Silver Montaza layer that recorded $(745 \mathrm{~g})$. This is may be because of the similar genetics between Silver Montaza and Matrouh strains where they have the same parent, which is Dokki-4 females.

\subsubsection{Effect of Ultraviolet (UV) light}

Egg mass wasn't significant affected by Ultraviolet light in all experimental period (Table 4).

These results correspond with those of Pyrzak and Siopes (1986) who didn't observed any effect of light color on egg production also Hassan et al (2013) indicated that egg production was similar in white, green and blue light color

\section{Physiological performance}

\subsection{Blood plasma analysis}

\subsubsection{Effect of strain}

Creatin and Aspartate Transaminase (AST) were significant affected $(P<0.05)$ by strain type (Table 5 and 6).

Matrouh developed strain recorded higher plasma Creatin (1.14) while Silver Montaza developed strain recorded lower value (0.93) (Table 6).

Matrouh developed strain recorded higher plasma AST (58.73 IU/L) while Silver Montaza developed strain recorded lower value (42.13 IU/L) (Table 6).
These consequences agree with Habeb et al (2007) who reported that there is no significant differences in plasma Total Protein (TP) also Hassan et al (2006) reported that there were no significant differences between fayoumi, Golden Montaza and Matrouh strains in serum Phosphorus, Total Protein and Albumin levels. On the other side, El-Kaiaty and Hassan (2004) reported that there were a significant differences between local strains for serum concentrations of Calcium, Globulin and T3 hormone.

\subsubsection{Effect of Ultraviolet light}

Plasma total protein, Globulin, Follicle Stimulating Hormones (FSH), Uric Acid (UA), Creatin, AST and Alanine Transaminase (ALT) were significant affected $(\mathrm{P}<0.05)$ by Ultraviolet light (Table $\mathbf{5}$ and 6).

Treatment 2 (1 hour UV light) recorded higher plasma total protein $(7.27 \mathrm{~g} / \mathrm{dl})$ compared with Treatment 4 (3 hour UV light) which recorded lower value $(6.30 \mathrm{~g} / \mathrm{dl})$.

Treatment 2 ( 1 hour UV light) recorded higher plasma globulin $(5.35 \mathrm{~g} / \mathrm{dl})$ compared with treatment 4 (3 hour UV light) which recorded lower value $(4.28 \mathrm{~g} / \mathrm{dl})$.

Treatment 4 and 5 ( 3 and 4 hour UV light) recorded higher Follicle Stimulating Hormones (FSH) (7.92 and 8.63 respectively) compared with other treatments.

Treatment 3 (2 hour UV light) recorded higher plasma Uric acid (6.40) than the other treatments and the lower value was treatment 5 (4 hour UV light) which recorded (4.40).

Treatment 3 and 4 ( 2 and 3 hour UV light) recorded higher plasma Creatin (1.25 and 1.17) compared with control treatment $(0.78)$.

Treatment 5 (4 hour UV light) recorded higher plasma AST (59.00 IU/L) compared with treatment 4 (3 hour UV light) that recorded (36.83 IU/L) lower value. Treatment 2 (1 hour UV light) recorded higher plasma ALT (39.33 IU/L) compared with treatment 5 (4 hour UV light) that recorded (19.00 $\mathrm{IU} / \mathrm{L})$ lower value. These are may be because of light color and intensity that effects on blood components.

These consequences agree with Olanrewaju et al (2006) who reported that Light affects physical activity, metabolic rate, and other physiological factors such as reproduction and hormonal status. 
Table 4. Egg mass $(\bar{X} \pm S E)$ of Silver Montaza and Matrouh layers as affected by Ultraviolet light during the different experimental period

\begin{tabular}{|c|c|c|c|c|c|c|}
\hline \multirow{2}{*}{ Treatment } & \multicolumn{6}{|c|}{ Egg mass (gm) } \\
\hline & $20-24$ & 24-28 & 28-32 & $32-36$ & $36-40$ & 20-40 wks \\
\hline Strain & NS & NS & NS & * & NS & NS \\
\hline Silver Montaza & $135.60 \pm 14.02$ & $540.42 \pm 28.33$ & $769.94 \pm 36.52$ & $745.44 \pm 27.65^{b}$ & $839.36 \pm 24.20$ & $606.15 \pm 21.60$ \\
\hline Matrouh & $135.00 \pm 15.19$ & $573.67 \pm 20.85$ & $800.77 \pm 19.76$ & $825.51 \pm 19.61^{\mathrm{a}}$ & $825.91 \pm 26.43$ & $632.17 \pm 15.45$ \\
\hline Ultraviolet light & NS & NS & NS & NS & NS & NS \\
\hline Without & $106.27 \pm 16.95$ & $513.86 \pm 54.64$ & $714.45 \pm 77.33$ & $726.47 \pm 50.47$ & $803.03 \pm 25.81$ & $572.82 \pm 39.85$ \\
\hline 1 hour & $150.93 \pm 15.52$ & $616.81 \pm 44.00$ & $847.43 \pm 41.54$ & $801.75 \pm 56.21$ & $870.84 \pm 59.04$ & $657.55 \pm 34.35$ \\
\hline 2 hour & $173.78 \pm 28.35$ & $590.83 \pm 35.01$ & $784.33 \pm 30.26$ & $788.27 \pm 23.50$ & $814.82 \pm 39.42$ & $630.41 \pm 25.30$ \\
\hline 3 hour & $137.15 \pm 18.54$ & $563.70 \pm 24.61$ & $768.74 \pm 34.59$ & $820.58 \pm 40.47$ & $857.86 \pm 26.97$ & $629.61 \pm 23.11$ \\
\hline 4 hour & $108.37 \pm 25.63$ & $500.02 \pm 14.48$ & $811.83 \pm 22.69$ & $790.32 \pm 27.31$ & $816.62 \pm 43.49$ & $605.43 \pm 18.81$ \\
\hline
\end{tabular}

Table 5. Blood Plasma analysis $(\bar{X} \pm S E)$ of Silver Montaza and Matrouh layers as affected by dietary Ultraviolet light at 40 weeks of ages

\begin{tabular}{|l|c|c|c|c|c|}
\hline \multirow{2}{*}{ Treatment } & \multicolumn{5}{|c|}{ Plasma analysis at 40 wks } \\
\cline { 2 - 6 } & $\begin{array}{c}\text { Total Protein (Tp) } \\
\text { (g/dl) }\end{array}$ & $\begin{array}{c}\text { Albumin (Al) } \\
\text { (g/dl) }\end{array}$ & $\begin{array}{c}\text { Globulin (Gl) } \\
\text { (g/dl) }\end{array}$ & T3 & (FSH) \\
\hline Strain & NS & NS & NS & NS & NS \\
Silver Montaza & $6.80 \pm 0.23$ & $1.98 \pm 0.05$ & $4.82 \pm 0.23$ & $1.27 \pm 0.07$ & $6.93 \pm 0.29$ \\
Matrouh & $6.85 \pm 0.27$ & $1.93 \pm 0.05$ & $4.92 \pm 0.29$ & $1.19 \pm 0.07$ & $7.25 \pm 0.36$ \\
\hline Ultraviolet light & $*$ & NS & $*$ & NS & $*$ \\
Without & $6.58 \pm 0.10^{\mathrm{ab}}$ & $1.93 \pm 0.08$ & $4.65 \pm 0.10^{\mathrm{ab}}$ & $1.15 \pm 0.15$ & $6.05 \pm 0.48^{\mathrm{b}}$ \\
1 hour & $7.27 \pm 0.67^{\mathrm{a}}$ & $1.92 \pm 0.05$ & $5.35 \pm 0.71^{\mathrm{a}}$ & $1.27 \pm 0.10$ & $6.53 \pm 0.24^{\mathrm{b}}$ \\
2 hour & $6.98 \pm 0.38^{\mathrm{ab}}$ & $1.93 \pm 0.04$ & $5.05 \pm 0.39^{\mathrm{ab}}$ & $1.39 \pm 0.04$ & $6.32 \pm 0.30^{\mathrm{b}}$ \\
3 hour & $6.30 \pm 0.16^{\mathrm{b}}$ & $2.02 \pm 0.09$ & $4.28 \pm 0.22^{\mathrm{b}}$ & $1.21 \pm 0.09$ & $7.92 \pm 0.30^{\mathrm{a}}$ \\
4 hour & $7.00 \pm 0.37^{\mathrm{ab}}$ & $1.99 \pm 0.11$ & $5.01 \pm 0.32^{\mathrm{ab}}$ & $1.16 \pm 0.16$ & $8.63 \pm 0.20^{\mathrm{a}}$ \\
\hline
\end{tabular}

$(\bar{X} \pm S E)=$ Average \pm standard error. $\quad \mathrm{NS}=$ Not significant.

$a$ and $b$ means having diverse letters at the similar column are significantly $(P \leq 0.05)$ different. 

response of two developed laying hens

Table 6. Blood plasma enzymes concentrations $(\bar{X} \pm S E)$ of silver Montaza and Matrouh layers as affected by dietary Ultraviolet light at 40 weeks of ages

\begin{tabular}{|l|c|c|c|c|}
\hline \multirow{2}{*}{ Treatment } & \multicolumn{4}{|c|}{ Blood plasma enzymes at 40 wks } \\
\cline { 2 - 5 } & Uric Acid (UA) & Creatin & AST (IU/L) & ALT (IU/L) \\
\hline Strain & NS & $*$ & $*$ & NS \\
Montaza silver & $5.24 \pm 0.32$ & $0.93 \pm 0.10^{\mathrm{b}}$ & $42.13 \pm 3.84^{\mathrm{b}}$ & $25.13 \pm 2.02$ \\
Matrouh & $5.14 \pm 0.29$ & $1.14 \pm 0.11^{\mathrm{a}}$ & $58.73 \pm 4.48^{\mathrm{a}}$ & $29.47 \pm 3.61$ \\
\hline UV light & $*$ & $*$ & $*$ & $*$ \\
Without & $5.03 \pm 0.36^{\mathrm{b}}$ & $0.78 \pm 0.17^{\mathrm{b}}$ & $54.17 \pm 8.76^{\mathrm{ab}}$ & $23.17 \pm 3.78^{\mathrm{bc}}$ \\
1 hour & $4.68 \pm 0.32^{\mathrm{b}}$ & $1.03 \pm 0.01^{\mathrm{ab}}$ & $45.83 \pm 7.75^{\mathrm{ab}}$ & $39.33 \pm 5.46^{\mathrm{a}}$ \\
2 hour & $6.40 \pm 0.24^{\mathrm{a}}$ & $1.25 \pm 0.14^{\mathrm{a}}$ & $56.33 \pm 6.70^{\mathrm{ab}}$ & $32.00 \pm 4.81^{\mathrm{ab}}$ \\
3 hour & $5.44 \pm 0.50^{\mathrm{ab}}$ & $1.17 \pm 0.25^{\mathrm{a}}$ & $36.83 \pm 7.36^{\mathrm{b}}$ & $23.00 \pm 1.48^{\mathrm{bc}}$ \\
4 hour & $4.40 \pm 0.54^{\mathrm{b}}$ & $0.95 \pm 0.16^{\mathrm{ab}}$ & $59.00 \pm 3.34^{\mathrm{a}}$ & $19.00 \pm 0.73^{\mathrm{c}}$ \\
\hline
\end{tabular}

\section{Immune Response}

\subsection{Blood analysis}

\subsubsection{Effect of strain}

Only white blood cells was significant affected $(\mathrm{P}<0.05)$ by strain type (Table 7 ).

Silver Montaza developed strain recorded higher white blood cells $\left(15.50 \mathrm{~mm}^{3}\right)$ while Matrouh developed strain recorded lower value (15.01 $\mathrm{mm}^{3}$ ). This is may be due to the difference in genetics between Silver Montaza and Matrouh strains.

These results agree with Enaiat et al (2010) who recorded that the higher value of blood $\mathrm{He}$ moglobin recorded by Silver Montaza females, while Matrouh females recorded the lowest. Also Carlander (2002) who reported that there are significant differences on immunoglobulin concentration among genetic lines or breeds.

On the other side, Rizk et al (2018) reported that Matrouh and Silver Montaza strains recorded no significant differences on immunoglobulin concentration.

\subsubsection{Effect of Ultraviolet light}

Hemoglobin, red blood cells, white blood cells, Packed cell volume (PCV), heterophils, Lymphocytes, Monocytes, Eosimophils and Basophils were significant affected $(\mathrm{P}<0.05)$ by Ultraviolet exposure time (Table 7 ).

Treatment 4 (3 hour UV light) recorded higher blood hemoglobin $(14.12 \mathrm{~g} / \mathrm{dl})$ compared with control treatment $(10.71 \mathrm{~g} / \mathrm{dl})$ (Table 7$)$.

Treatment 2, 3 and 4 (1, 2 and 3 hour UV light) recorded higher red blood cells $(3.58,3.57$ and $3.92\left(10 / \mathrm{mm}^{3}\right)$ respectively) compared with other treatment.

Treatment 3 and 4 ( 2 and 3 hour UV light) recorded higher white blood cells (16.26 and 16.11 $\left(10 / \mathrm{mm}^{3}\right)$ respectively) compared with other treatment.

Treatment 3 and 4 ( 2 and 3 hour UV light) recorded higher PCV (35.16 and 36.20 respectively) compared with other treatment.

Treatment 3 and 4 (2 and 3 hour UV light) recorded higher heterophils \% (28.55 and $28.78 \%$ respectively) compared with other treatment.

Treatment 3 and 4 ( 2 and 3 hour UV light) recorded higher lymphocytes \% (66.85 and $68.37 \%$ respectively) compared with other treatment. 
Table 7. Blood analysis $(\bar{X} \pm S E)$ of Silver Montaza and Matrouh layers as affected by Ultraviolet light at 40 weeks of ages

\begin{tabular}{|c|c|c|c|c|c|c|c|c|c|}
\hline \multirow[b]{2}{*}{ Treatment } & \multicolumn{9}{|c|}{ Blood analysis } \\
\hline & $\begin{array}{c}\text { Hemoglobin } \\
(\mathrm{g} / \mathrm{dl})\end{array}$ & $\begin{array}{c}\text { Red } \\
\text { blood } \\
\text { cells } \\
(10 \\
/ \mathrm{mm} 3)\end{array}$ & $\begin{array}{l}\text { White } \\
\text { blood } \\
\text { cells } \\
(10 / \mathrm{mm} 3)\end{array}$ & PCV & $\begin{array}{c}\text { Heterophils } \\
(\%)\end{array}$ & $\begin{array}{c}\text { Lymphocytes } \\
\text { (\%) }\end{array}$ & $\begin{array}{c}\text { Monocytes } \\
(\%)\end{array}$ & $\begin{array}{c}\text { Eosimophils } \\
(\%)\end{array}$ & $\begin{array}{c}\text { Basophils } \\
(\%)\end{array}$ \\
\hline Strain & NS & NS & * & NS & NS & NS & NS & NS & NS \\
\hline Silver Montaza & $\begin{array}{c}12.69 \pm \\
0.39\end{array}$ & $\begin{array}{c}3.24 \pm \\
0.13\end{array}$ & $\begin{array}{c}15.50 \pm \\
0.28^{a}\end{array}$ & $\begin{array}{c}33.41 \pm \\
0.60\end{array}$ & $\begin{array}{c}27.52 \pm \\
0.36\end{array}$ & $\begin{array}{c}64.89 \pm \\
0.67\end{array}$ & $\begin{array}{c}5.17 \pm \\
0.29\end{array}$ & $\begin{array}{c}3.50 \pm \\
0.10\end{array}$ & $\begin{array}{l}1.38 \pm \\
0.07\end{array}$ \\
\hline Matrouh & $\begin{array}{c}12.22 \pm \\
0.40\end{array}$ & $\begin{array}{c}3.45 \pm \\
0.16\end{array}$ & $\begin{array}{c}15.01 \pm \\
0.28^{b}\end{array}$ & $\begin{array}{c}32.73 \pm \\
0.85\end{array}$ & $\begin{array}{c}27.22 \pm \\
0.39\end{array}$ & $\begin{array}{c}65.83 \pm \\
0.71\end{array}$ & $\begin{array}{c}5.51 \pm \\
0.34\end{array}$ & $\begin{array}{c}3.86 \pm \\
0.17\end{array}$ & $\begin{array}{l}1.52 \pm \\
0.08\end{array}$ \\
\hline \begin{tabular}{|l|} 
Ultraviolet \\
light
\end{tabular} & * & * & * & * & * & * & * & * & * \\
\hline Without & $\begin{array}{c}10.71 \pm \\
0.22^{d}\end{array}$ & $\begin{array}{l}2.80 \pm \\
0.08^{b}\end{array}$ & $\begin{array}{c}13.91 \pm \\
0.25^{c}\end{array}$ & $\begin{array}{c}29.89 \pm \\
0.44^{c}\end{array}$ & $\begin{array}{c}25.69 \pm \\
0.31^{c}\end{array}$ & $\begin{array}{c}62.76 \pm \\
0.82^{\mathrm{b}}\end{array}$ & $\begin{array}{l}3.99 \pm \\
0.08^{b}\end{array}$ & $\begin{array}{l}3.24 \pm \\
0.17^{b}\end{array}$ & $\begin{array}{l}1.18 \pm \\
0.09^{c}\end{array}$ \\
\hline 1 hour & $\begin{array}{l}12.70 \pm \\
0.51^{\mathrm{bc}}\end{array}$ & $\begin{array}{l}3.58 \pm \\
0.23^{\mathrm{a}}\end{array}$ & $\begin{array}{c}15.26 \pm \\
0.34^{b}\end{array}$ & $\begin{array}{c}33.41 \pm \\
0.51^{\mathrm{b}}\end{array}$ & $\begin{array}{c}27.61 \pm \\
0.37^{b}\end{array}$ & $\begin{array}{c}64.66 \pm \\
0.46^{\mathrm{b}}\end{array}$ & $\begin{array}{l}5.71 \pm \\
0.40^{\mathrm{a}}\end{array}$ & $\begin{array}{l}3.54 \pm \\
0.16^{\mathrm{ab}}\end{array}$ & $\begin{array}{l}1.49 \pm \\
0.08^{b}\end{array}$ \\
\hline 2 hour & $\begin{array}{l}13.16 \pm \\
0.37^{\mathrm{ab}}\end{array}$ & $\begin{array}{l}3.57 \pm \\
0.21^{\mathrm{a}}\end{array}$ & $\begin{array}{c}16.26 \pm \\
0.28^{\mathrm{a}}\end{array}$ & $\begin{array}{c}35.16 \pm \\
0.68^{\mathrm{a}}\end{array}$ & $\begin{array}{c}28.55 \pm \\
0.17^{\mathrm{a}}\end{array}$ & $\begin{array}{c}66.85 \pm \\
0.95^{\mathrm{a}}\end{array}$ & $\begin{array}{l}6.22 \pm \\
0.27^{a}\end{array}$ & $\begin{array}{l}3.72 \pm \\
0.15^{\mathrm{ab}}\end{array}$ & $\begin{array}{l}1.79 \pm \\
0.05^{\mathrm{a}}\end{array}$ \\
\hline 3 hour & $\begin{array}{c}14.12 \pm \\
0.36^{\mathrm{a}}\end{array}$ & $\begin{array}{l}3.92 \pm \\
0.10^{\mathrm{a}}\end{array}$ & $\begin{array}{c}16.11 \pm \\
0.22^{\mathrm{a}}\end{array}$ & $\begin{array}{c}36.20 \pm \\
0.41^{a}\end{array}$ & $\begin{array}{c}28.78 \pm \\
0.34^{\mathrm{a}}\end{array}$ & $\begin{array}{c}68.37 \pm \\
0.54^{\mathrm{a}}\end{array}$ & $\begin{array}{l}6.45 \pm \\
0.31^{\mathrm{a}}\end{array}$ & $\begin{array}{l}4.41 \pm \\
0.30^{\mathrm{a}}\end{array}$ & $\begin{array}{l}1.49 \pm \\
0.11^{b}\end{array}$ \\
\hline 4 hour & $\begin{array}{l}11.60 \pm \\
0.45^{\text {cd }}\end{array}$ & $\begin{array}{l}2.86 \pm \\
0.07^{\mathrm{b}}\end{array}$ & $\begin{array}{c}14.73 \pm \\
0.24^{\mathrm{b}}\end{array}$ & $\begin{array}{c}30.69 \pm \\
0.78^{c}\end{array}$ & $\begin{array}{c}26.21 \pm \\
0.30^{c}\end{array}$ & $\begin{array}{c}64.17 \pm \\
0.90^{\mathrm{b}}\end{array}$ & $\begin{array}{l}4.33 \pm \\
0.35^{b}\end{array}$ & $\begin{array}{l}3.77 \pm \\
0.21^{\mathrm{ab}}\end{array}$ & $\begin{array}{l}1.32 \pm \\
0.12^{\mathrm{bc}}\end{array}$ \\
\hline
\end{tabular}

$(\bar{X} \pm S E)=$ Average \pm standard error. NS= Not significant.

$a, b$ and $c$ means having diverse letters at the similar column are significantly $(P \leq 0.05)$ different.

Treatment 2, 3 and 4 (1, 2 and 3 hour UV light) recorded higher monocytes \% (5.71, 6.22 and 6.45 $\%$ respectively) compared with other treatment.

Treatment 4 (3 hour UV light) recorded higher Eosimophils \% (4.41\%) compared with control treatment $(3.24 \%)$.

Treatment 3 ( 2 hour UV light) recorded higher Basophils \% (1.79 \%) compared with control treatment $(1.18 \%)$.

This may be because of the influence of Ultraviolet radiation wavelength on environment surrounding the birds that leads to improve immune system without a harmful effect in birds.

These consequences agree with Coufal et al (2003) who reported that In poultry, UV was the most commonly used for egg disinfection with not negative influence on the embryo. Also Koutchma et al (2009) said that UV dose requirements for destroying microbial cells.

\subsection{Sheep Red Blood Cells (SRBCs)}

\subsubsection{Effect of strain}

There were no significant affected $(P<0.05)$ both first and second Sheep Red Blood Cells (SRBCs) by strain type (Table 8). This is may be because of the similar genetics between Silver Montaza and Matrouh strains where they have the same parent, which is Dokki-4 females.

\subsubsection{Effect of Ultraviolet light}

Both the first and second SRBCs were significant affected $(P<0.05)$ by Ultraviolet exposure time (Table 8).

Control treatment recorded higher first SRBCs (7.17) compared with treatment 4 (3 hour UV light) that recorded lower value (4.50). 

response of two developed laying hens

Treatment 5 (4 hour UV light) recorded higher second SRBCs (5.83) compared with treatment 2 and 4 ( 1 and 3 hour UV light) that recorded lower values (3.83 and 4.17 respectively).

We used a test of Sheep Red Blood Cells (SRBCs) as indicator to viral infection. This may be because of the influence of Ultraviolet light wavelength on enhancing immune system in birds and a negative effect of Ultraviolet wavelength on viral activity. These consequences agree with $\mathrm{Xie}$ et al (2008) who found that the anti- New Castle (NDV) antibody titers were greater with using monochromatic light which improving antibody production in broilers. Also Kamlang et al (2006) who reported that UV light may be used to terminate avian influenza virus (AIV) in infected fecal material

Table 8. Plasma analysis $(\bar{X} \pm S E)$ of Silver Montaza and Matrouh layers as affected by dietary Ultraviolet light at 40 weeks of ages

\begin{tabular}{|l|c|c|}
\hline \multirow{2}{*}{ Treatment } & \multicolumn{2}{|c|}{ Plasma analysis } \\
\cline { 2 - 3 } & \multicolumn{2}{|c|}{ SRBCs } \\
\cline { 2 - 3 } & Frist & Second \\
\hline Strain & NS & NS \\
Silver Montaza & $6.07 \pm 0.58$ & $4.53 \pm 0.29$ \\
Matrouh & $5.27 \pm 0.52$ & $4.67 \pm 0.46$ \\
\hline Ultraviolet light & $*$ & $*$ \\
Without & $7.17 \pm 1.01^{\mathrm{a}}$ & $4.33 \pm 0.71^{\mathrm{ab}}$ \\
1 hour & $5.50 \pm 0.76^{\mathrm{ab}}$ & $3.83 \pm 0.31^{\mathrm{b}}$ \\
2 hour & $5.33 \pm 0.76^{\mathrm{ab}}$ & $4.83 \pm 0.65^{\mathrm{ab}}$ \\
3 hour & $4.50 \pm 0.62^{\mathrm{b}}$ & $4.17 \pm 0.17^{\mathrm{b}}$ \\
4 hour & $5.83 \pm 1.05^{\mathrm{ab}}$ & $5.83 \pm 0.75^{\mathrm{a}}$ \\
\hline
\end{tabular}

$(\bar{X} \pm S E)=$ Average \pm standard error.

$\mathrm{NS}=$ Not significant.

$\mathrm{a}$ and $\mathrm{b}$ means having diverse letters at the similar column are significantly $(\mathrm{P} \leq 0.05)$ different.

\section{CONCLUSION}

From the previous results, it could be concluded that supplemented program light in poultry breeding farmhouses (developed laying hens) with artificial source of UV light by UV lamps after sunset improved productive, physiological performance and immune responses.

From the previous results, it could be concluded that the efficient exposed time to UV lamps was (2-3 hours/day) for silver Montaza and Matrouh developed local strain.

\section{REFERENCES}

Benjamin L. and Hitchner S.B. 1980. Immunosuppression and active response induced by infectious bursal disease virus in chickens with passive antibodies. Avian Dis., 24(1), 189-196.

Carien M.V. and Tina M.W. 2003. A comparison of the productivity and behaviour of broiler breeders illuminated by various light sources. Amin. Welfare, 12(2), 269-288.

Carlander D. 2002. Avian IgY antibody, In Vitro and In Vivo Ph.D. Thesis: University of Uppsala, Faculty of Medic, Dept. of Med. Sci. 53 p., (Sweden).

Coufal C., Chavez C., Knape K. and Carey J. 2003. Evaluation of a method of ultraviolet light sanitation of broiler hatching eggs. Poult. Sci. 82, 754-759.

Davies R.H. and Breslin M. 2003. Investigation of Salmonella contamination and disinfection in farm egg-packing plants. J. of Applied Microbiology, 94, 191-196.

De Reu K., Grijspeerdt K., Heyndrickx M., Zoons J., De Baere D., Uyttendaele M., Debevere J. and Herman L. 2005. Bacterial eggshell contamination in conventional cages, furnished cages and aviary housing systems. British Poultry Sci., 46, 149-155.

Duncan D.B. 1955. Multiple range and $\mathrm{F}$ test. Biometric, 11, 1-42.

El-Hossari M.A. and Dorgham S.A. 1992. Economic evaluation of local chicken crosses under control environmental houses. Egypt. Poult. Sci., 12(2), 843- 866.

El-Kaiaty A.M. and Hassan M.S.H. 2004. Some physiological and immunological parameters in the female of local chicken strains. Egypt. Poult. Sci., 24, 901- 916.

Enaiat M.M. El-Anwer, Amina, A. Salem and Eman M. Abou-Eitta 2010. A competitive study of productive and physiological performance between two local strains of chicks. Egypt. Poult. Sci., 30(I), 297-316.

Gao F., Stewart L.E., Joseph S.W. and Carr L.E. 1997. Effectiveness of ultraviolet irradiation in reducing the numbers of Salmonella on eggs and egg belt conveyor materials. Appl. Engineering in Agric.. 13(3), 355-359.

Gornowicz E. 2004. Mikrobiologiczna ocena środowiska brojlerni w zależności od dodatku kwasów organicznych do pasz. Med. Wet., 60(7), 755-758.

Güntürkün O. 2000. Sensory Physiology: Vision. Sturkies avian physiology, $5^{\text {th }}$ Ed. Academic Press, USA, pp. 1-19. 
Habeb A.R.H., El-Tantawy S.M.T., Atta A.M. and Bakir A.A. 2007. A comparative study of meat and egg production and some physiological aspects in some local strains of chickens. M.Sc. Thesis, Fac. Agric., Cairo. Univ., Egypt, pp. 59-63.

Hassan M.S.H., Elsoudany S.M.M. and Roushdy Kh. 2006. In vivo study of intestinal calcium and phosphorus absorption at different stages of egg formation in the reproductive tract of high and low egg production laying hens. Egypt. Poult. Sci., 26, 297- 317.

Hassan R.M., Sultana S., Sung H.H. and Saon R.K. 2013. Effect of monochromatic and combined light color on performance, blood parameters, ovarian morphology and reproductive hormones in laying hens. Italian J. of Animal Sci., 12, 1-6.

Hogsette J. A., and Wilson H.R. 1999. Effects on Commercial Broiler Chicks of Constant Exposure to Ultraviolet Light from Insect Traps. Egypt. Poult. Sci., 78, 324-326.

Hogsette J.A., Wilson H.R. and SempleRowland S.L. 1997. Effects of constant exposure to ultraviolet light from insect traps on White Leghorn hens. Poultry Sci. 76, 11341137.

Kamlang C., Namphung S., Nakrop S., Bopit P. and Kridsada C. 2006. The effect of temperature and Ultraviolet light on infectivity of avian influenza virus (H5N1, Thai field strain) in chicken fecal manure. 37(1), 102-105.

Koutchma T., Forney L.J. and Moraru C.I. 2009. Ultraviolet light in food technology: Principles and applications. Boca Raton, Fla.: CRC press ID.-13, pp. 978-981.

Lewis P.D. and Morris T.R. 2000. Poultry and coloured light. World's Poultry Sci. J., 56, 189207.

Lu H., Castro A.E., Pennick K., Liu J., Yang Q., Dunn P., Weinstock D. and Henzler D. 2003. Survival of avian influenza virus H7N2 in SPF chickens and their environment. Avian Dis., 47(S 3), 1015-1021.

Mahmoud T.H., Madkour Y.H., Sayed I.F. and Harirah K.M. 1974 a. "Matrouh" a new breed of chickens. Agric. Res. Rev., 52, 87-96.

Mahmoud T.H., Sayed I.F. and Madkour Y.H. 1974 b. The "Silver Montazah" a new variety of chickens. Agric. Res. Rev., 52, 97-105.
Mitchell R.D., Edwards H.M. and Mcdaniel G.R. 1997. The Effects of Ultraviolet Light and Cholecalciferol and its Metabolites on the Development of Leg Abnormalities in Chickens Genetically Selected for a High and Low Incidence of Tibial Dyschondroplasia. Poultry Sci., 76, 346354.

Miyamoto T., Baba E., Tanaka T., Sasai K., Fukata T. and Arakawa A. 1997. Salmonella enteretidis contamination of eggs from hens inoculated by vaginal, cloacal and intravenous routes. Avian Diseases, 34, 463-465.

Olanrewaju H.A., Thaxton J.P., Dozier W.A., Purswe J., Roush W.B. and Branton S.L. 2006. A Review of Lighting Programs for Broiler Production. Int. J. of Poult. Sci., 5(4), 301-308.

Pyrzak R. and Siopes T.D. 1986. The effect of color light on egg quality of turkey hens in cage. Poultry Sci., 65, 1262-1267.

Rizk A.M., Osama A. El-Sayed; Qurtam A.A., Alkilani W.H. and Ahmed M.S. 2018. Immunoglobulin lgy transfer from Dams to their egg yolks and chicks in some local developed Egyptian Strains. Egypt. Poult. Sci. 38(IV), 11411154.

Roy P., Dhillon A.S., Lauerman L.H., Schaberg D.M., Bandli D. and Johnson S. 2002. Results of salmonella isolation from poultry products, poultry environment, and other characteristics. Avian Dis., 46, 17-24.

Ryer, A., 1997. Light measurement handbook. International Light Inc. Newburyport, 6 p.

SAS institute 2001. SAS User Guide Statistics Version $10^{\text {th }}, 16 \mathrm{Ed}$., SAS Inst., Cary, NC.

Turtoi M. and Borda D. 2014. Decontamination of egg shells using Ultraviolet light treatment. World's Poultry Sci. J. 70(2), 265-278.

Xie D., Wang Z.X., Dong Y.L., Cao J., Wang J.F., Chen J.L. and Chen Y.X. 2008. Effects of monochromatic light on immune response of broilers. Poultry Sci., 87(10), 1535-1539.

Zhang Lan-xia, Shi Zheng-xiangl, Wang $X$. yingl, Geng Ai-lianl and Bao-mingl L.I. 2006. Effects of ultraviolet radiation on skeleton development of broiler chickens. Agric. Sci. in China. S(4), 313-317.

Zhang R.H. 2000. Effect of exercise and calcium supplementation on EMD and bone metabolism of organism. M.Sc. Thesis, Beijing Medical Univ.. Beijing. 4 p. 


\begin{tabular}{|c|c|c|}
\hline & 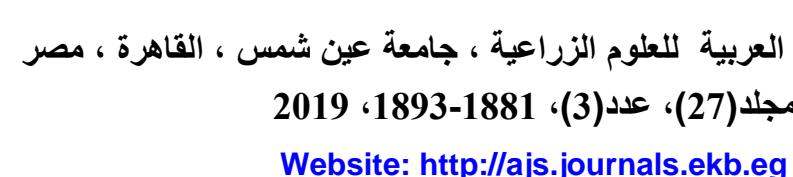 & 国 \\
\hline 1893 & & \\
\hline
\end{tabular}

تأثير الأشعة فوق البنفسجية على الآداء الإنتاجي والفسيولوجي والإستجابة المناعية

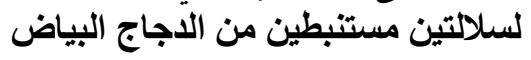

[150]

أحمد محمد ضيف يوسف1" - إبراهيم الورداني2-- مجدي سيد حسن حسن 1 - مبدالـ

محمد إبراهيم عبدالله شُُّرَّاب 2

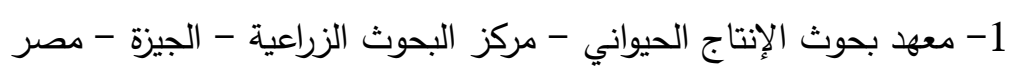

2- قسم انتاج الدواجن - كلية الزراعة - جامعة عين شمس - ص.ب. 68 - حدائق شبرا 11241 - القاهرة -

مصر

*Corresponding author: a_youssef007@yahoo.com

Received 6 May, 2019

Accepted 4 September, 2019

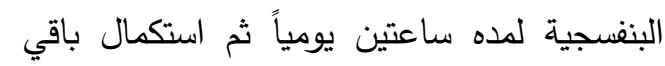

مدة برنامج الإضاءة بالتعرض للمبن للمبات الصفراء.

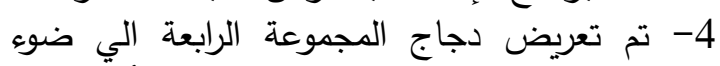

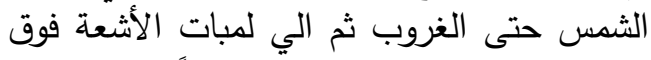

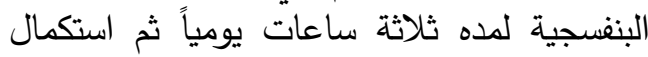

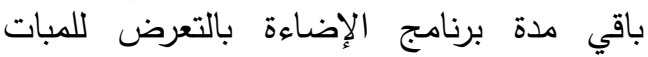

الصغراء.

5- تم تعريض دجاه المجموعة الخامسة الي ضوء المباء

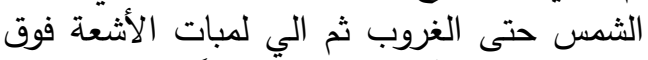

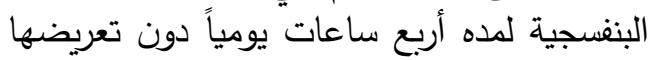

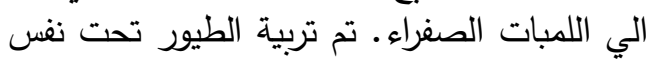

$$
\text { الظروف الرعائية. }
$$

أظهرت النتائج حدوث تحسن الظعن معنوي في وزن

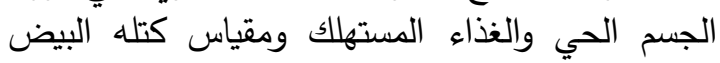

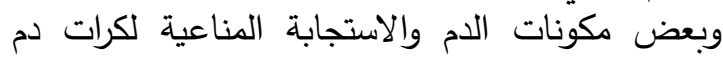
الغنم الحمراء وذلك نتيجة التعرض للمبات الاتبات الثعة فوق

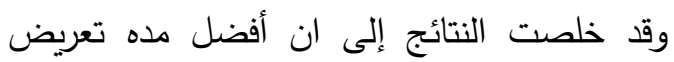

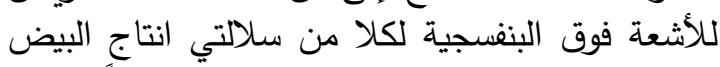

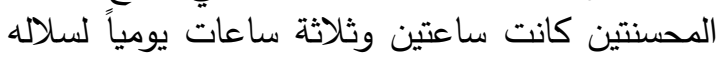
المنتزه الفضي وسلاله المطروح على التوالي.

الكلمات الدالة: لمبات الأشعة فوق البنفسجية، الاجاج البياض، برامج الإضاءة، الآداء الإنتاجي لئي

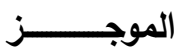

استخدم في هذه الدراسة عدد 165 طائر (150)

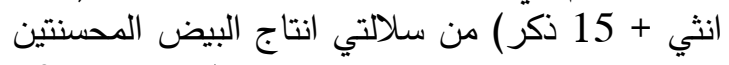

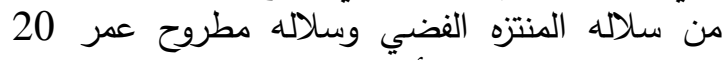
اسبوع وحتى عمر 40 أسبوع.

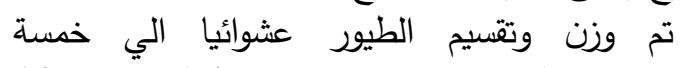
مجموعات بكل منها ثناثة مكررات (بكل مكرر 10

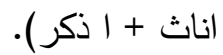
تم تعريض مجموعات التجربة الي ضوض ضوء النهار

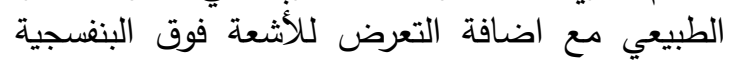

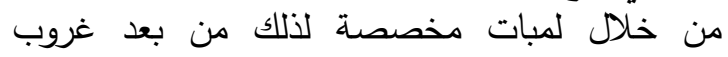
الثمس وذلك باستخدام مؤقتات تشغيل (تايمر) وذلك لثرب كما يلي: 1- تم تعريض دجاج المجموعة الاولي (مجموعة

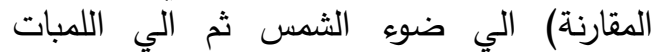

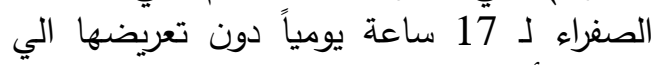
لمبات الأشعة فوق البنفجية.

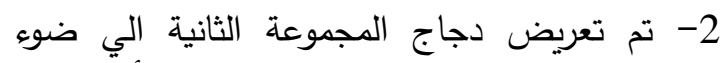

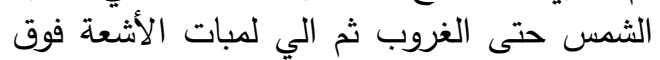

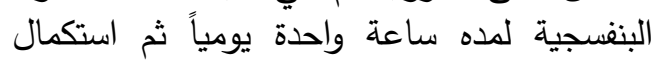

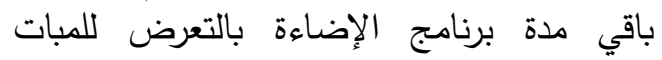
الصفراء.

3- تم تعريض دجاج المجموعة الثالثة الي ضوء الثاء

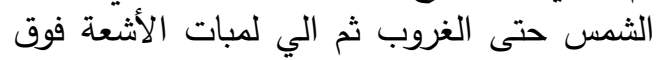


